\title{
BIS
}

\section{No 5}

Emerging market economy exchange rates and local currency bond markets amid the Covid-19 pandemic

Boris Hofmann, Ilhyock Shim and Hyun Song Shin 
BIS Bulletins are written by staff members of the Bank for International Settlements, and from time to time by other economists, and are published by the Bank. The papers are on subjects of topical interest and are technical in character. The views expressed in them are those of their authors and not necessarily the views of the BIS. The authors are grateful to Jimmy Shek for excellent analysis and research assistance, and to Louisa Wagner for administrative support.

The editor of the BIS Bulletin series is Hyun Song Shin.

This publication is available on the BIS website (www.bis.org).

(C) Bank for International Settlements 2020. All rights reserved. Brief excerpts may be reproduced or translated provided the source is stated. 


\section{Emerging market economy exchange rates and local currency bond markets amid the Covid-19 pandemic}

\section{Key takeaways}

- Borrowing through domestic currency bonds has not insulated emerging market economies (EMEs) from the financial shock unleashed by Covid-19; EME local currency bond spreads spiked amid sharp currency depreciations and capital outflows.

- Portfolio investors face amplified losses as local currency spreads and exchange rates move in lockstep; their revised portfolio allocations in turn strengthen this correlation.

- EMEs with monetary policy frameworks that are equipped to address the feedback loop between exchange rate depreciation and capital outflows stand a better chance of weathering the financial fallout from the Covid-19 pandemic.

- To counter large stock adjustments in domestic bond markets, EME central banks may need to expand their toolkit to take on a "dealer of last resort" role; a number of them are already moving in this direction.

The Covid-19 pandemic has sparked widespread and synchronised recoiling from risk that has hit emerging market economies (EMEs) particularly hard. The focus of this Bulletin is on local currency bond markets. Borrowing in domestic currency has not insulated EMEs from currency movements, as sharp currency declines have set in motion amplifying dynamics in the financial system between record portfolio outflows in EME bonds (Graph 1, left-hand panel) and the spike in EME local currency bond spreads over international benchmarks (right-hand panel).

These recent events have exposed in a particularly stark way the financial channel of the exchange rate (BIS (2019)), ie the amplifying and mutually reinforcing interactions of currency fluctuations and financial market outcomes in EMEs, particularly in EME local currency bond markets. This article lays out the key mechanisms of this channel and how they have played out in recent weeks. We also draw lessons for EME central banks and for their monetary policy frameworks as they weather the financial fallout from the Covid-19 pandemic. 


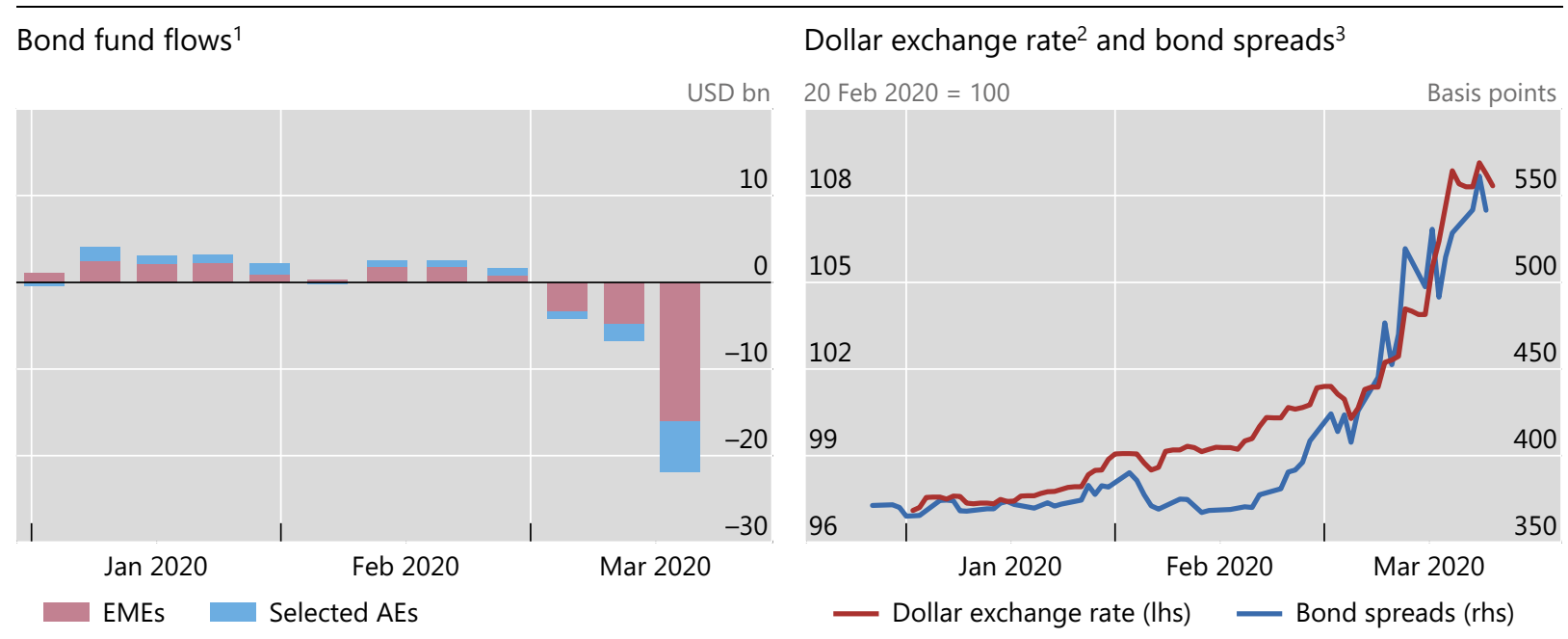

1 Weekly data across major emerging market economies (EMEs) and selected advanced economies (AEs) (Canada and the United Kingdom) up to 18 March 2020 from EPFR. Data cover net portfolio flows (adjusted for exchange rate changes) to dedicated funds for individual EMEs and selected AEs and to EME funds with country/regional decomposition. 2 Simple averages of EMEs excluding China. An increase indicates USD appreciation. 3 Spread between the yield of the GBI-EM Broad index excluding China, 7-10 years, over benchmark US Treasury yield.

Sources: Bloomberg; EPFR; national data; BIS calculations.

\section{"Original sin redux"}

A key lesson from the EME financial crises of the 1990s was that currency mismatches combined with maturity mismatches gave rise to a vulnerability to capital outflows. In reaction, EMEs developed local currency bond markets in long maturities to overcome so-called "original sin", of not being able to borrow internationally in their domestic currency (Eichengreen and Hausmann (1999)). While EME corporates still rely on foreign currency credit, EME sovereigns have increasingly turned to local currency issuance. Indeed, local currency bond markets in EMEs now represent the lion's share of outstanding bonds in EMEs.

Owing to their smaller domestic institutional investor base, EME bond markets have relied on external portfolio investors for their growth (Graph 2, left-hand panel). If these investors evaluate gains and losses in terms of dollars or other advanced economy currencies, unhedged holdings of EME local currency bonds increase the risk exposure for the investors, giving rise to a potentially greater sensitivity of holdings to shifts in measured risks. As a consequence, reliance on foreign external portfolio capital leads to a greater vulnerability to global financial shocks, as such capital can be more flighty in times of stress (HKMA (2019)). Indeed, EMEs with higher shares of foreign ownership in their local currency bond markets have experienced significantly larger increases in their local currency bond spreads in the wake of the Covid-19 pandemic (Graph 2, right-hand panel).

The exchange rate plays an important amplifying role in the portfolio adjustment of global investors. Borrowing in local currency from foreign lenders mitigates currency mismatch for the borrower but shifts the currency mismatches to the lender's balance sheets - a phenomenon dubbed "original sin redux" by Carstens and Shin (2019), and explained further in BIS (2019). The lenders have assets in foreign currency but obligations to beneficiaries or policyholders in their own currency. In this context, a generalised EME currency depreciation further lowers the value of assets in the foreign investors' home currency terms, tightening their risk constraints more than otherwise. When risk capacity is limited, EME currency depreciation may trigger sales or ex post hedging, pushing up EME bond spreads due to the exit of foreign investors. The same mechanism plays out in reverse when EME exchange rates appreciate. The gains to foreign investors are amplified by EME currency appreciation, leading to inflows. 
Foreign ownership in local currency sovereign bond markets $^{1}$

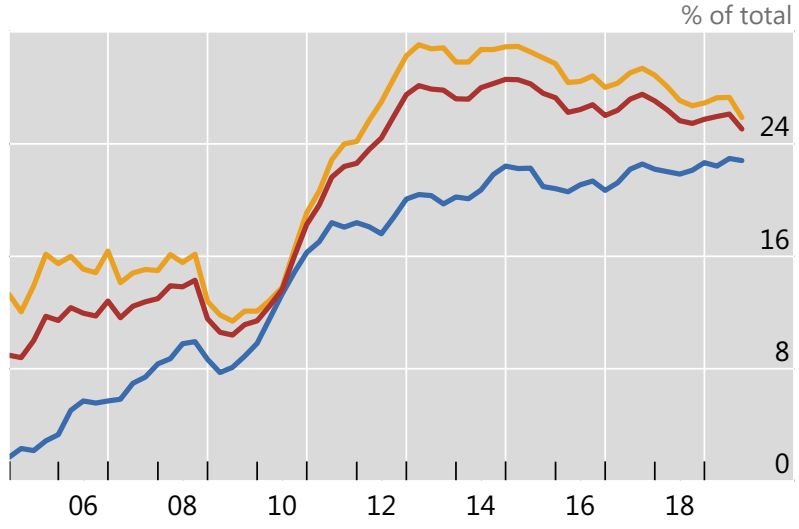

- EMEs — Asian EMEs — Other EMEs
Scatter plot of changes in local currency yield spreads ${ }^{2}$ versus the level of foreign holdings

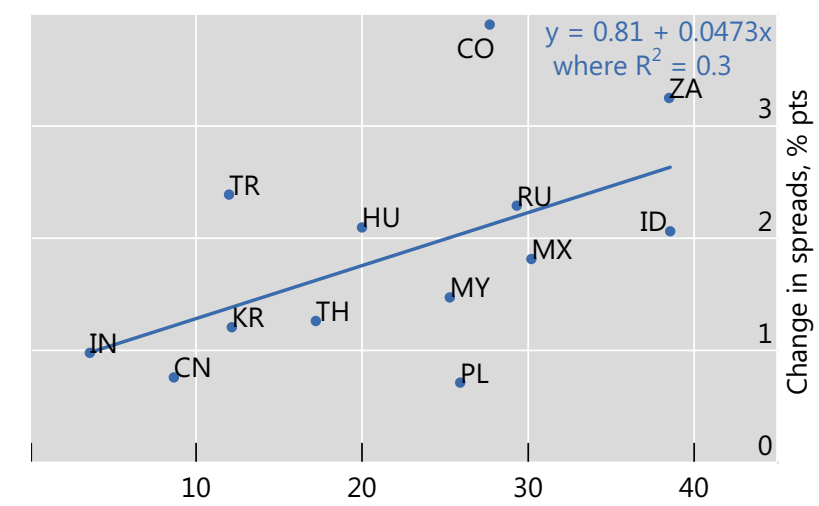

Foreign holdings, Q4 2019 or latest, ${ }^{3}$ in per cent

1 Simple averages, excluding $C L, C Z, I N, P H$ and $R U$ due to data availability. ${ }^{2}$ Change in five-year generic local currency sovereign yield spread over the US Treasury of the same tenor. 3 For yield spreads, change from 3 January 2020 to 23 March 2020; for foreign holdings, Q4 2019 except for: China and India, Q2 2019, and Korea and Thailand, Q3 2019.

Sources: Arslanalp and Tsuda (2014); AsianBondOnline; Bloomberg; Institute of International Finance.

The tight embrace between exchange rates and local currency bond prices can be seen by comparing the returns of bond funds in local currency terms and in US dollar terms (Graph 3). For EME bonds, US dollar returns are more sensitive to yield changes than local currency returns (the red lines are steeper than the blue lines). The relationship between exchange rates and yields in the most recent period (Graph 3, top right-hand panel) has conformed to the general pattern observed over a longer period of time (top left-hand panel). The "duration" of EME bonds (defined as the sensitivity of the bond return to shifts in the yield) tends to be larger in dollar terms than in local currency terms. For investors that evaluate returns in dollar terms, EME bonds thus have the duration risk of much longer maturity bonds, as exchange rate moves tend to amplify investors' gains and losses. In this sense, exchange rate changes reinforce the impact of yield changes, in turn amplified by capital flows. For advanced economies, by contrast, duration in local currency terms was higher than in US dollar terms in the pre-Covid-19 period (Graph 3, bottom left-hand panel), suggesting that here the exchange rate dampened the impact on investor returns. However, ever since the Covid-19 outbreak started going global, bond returns in advanced economies have displayed a pattern more similar to that in EMEs (bottom right-hand panel).

The procyclical mechanism laid out above is one key reason why EME sovereign spreads tend to increase when the currency of the issuer depreciates (Graph 4, left-hand panel). It has played out forcefully since 2013, a period characterised by a large depreciation of many EME currencies against the US dollar, including during the taper tantrum period. The graph shows how the link reasserted itself strongly in early 2020, when EME exchange rates depreciated and bond spreads shot up sharply. 


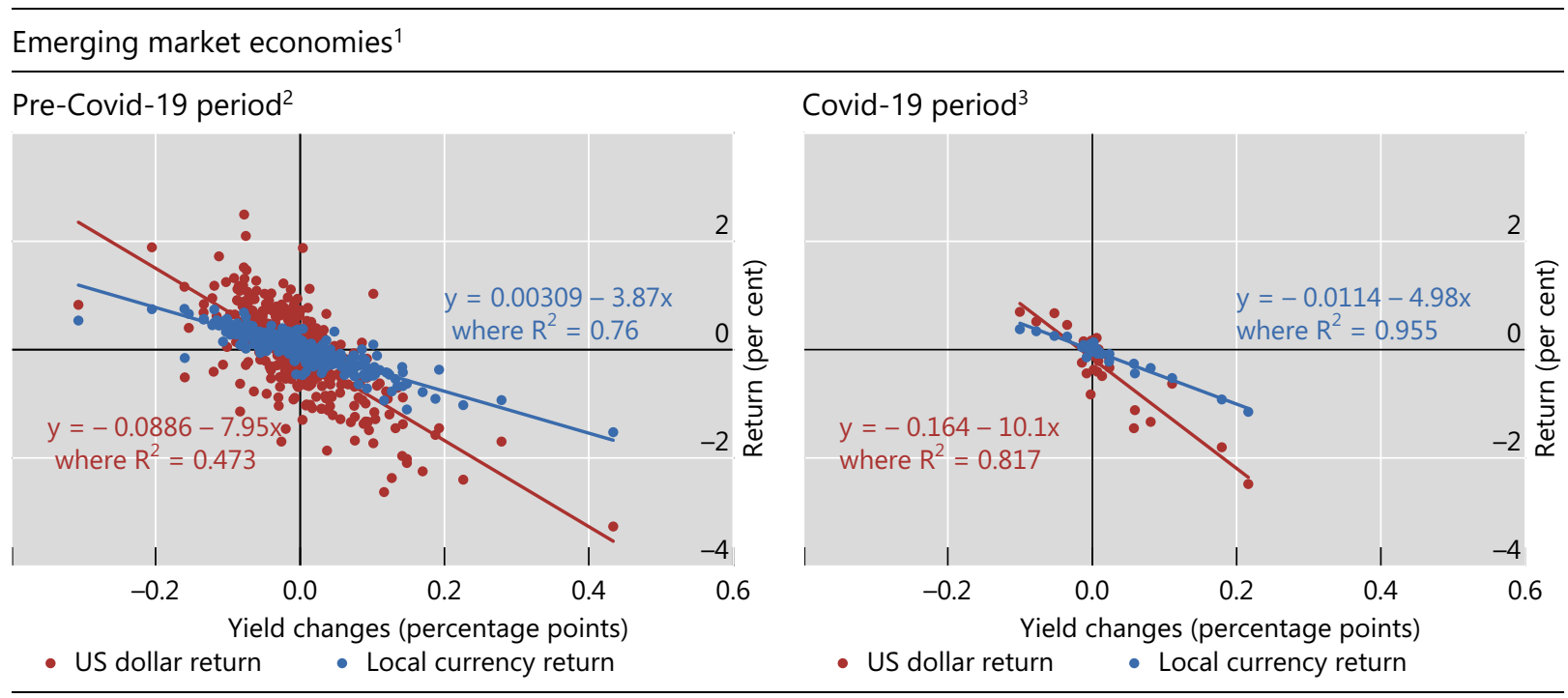

Advanced economies ${ }^{4}$
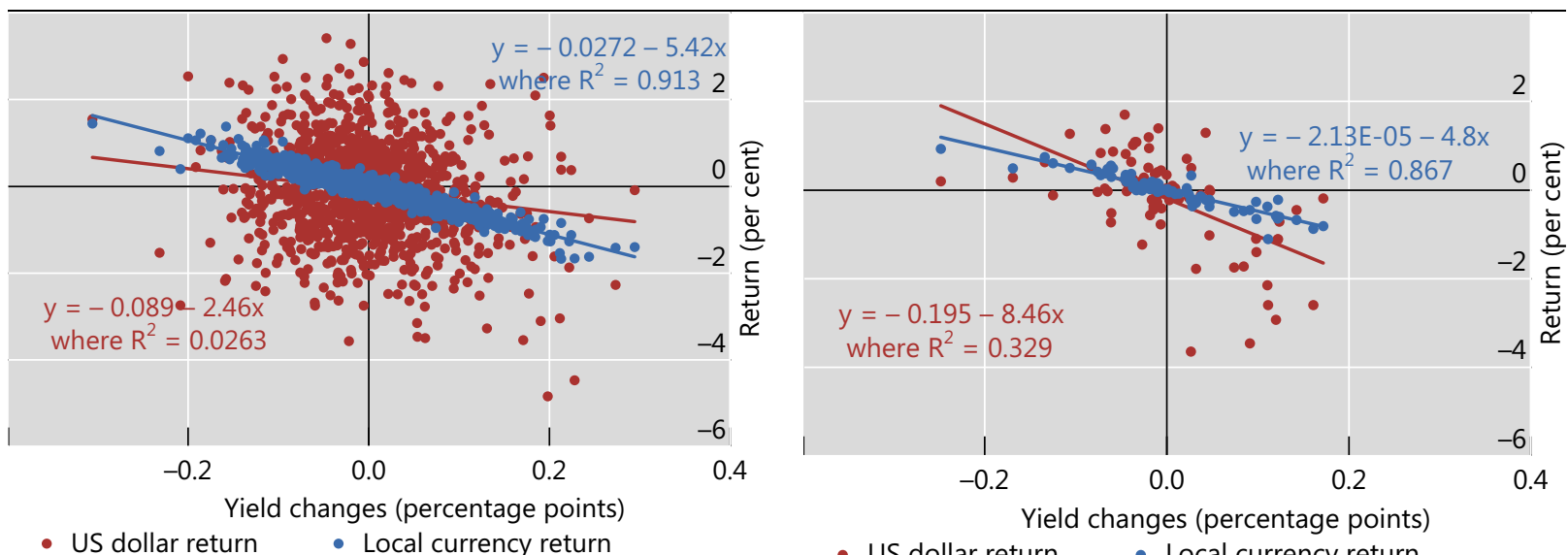

- US dollar return - Local currency return

- US dollar return - Local currency return

1 GBI-EM Broad 5-7 years, principal return in the US dollar and in local currency against yield change. 2 January 2013 to 10 February 2020, weekly data. 311 February 2020 to 23 March 2020, daily data. 4 GBI Broad 5-7 years for Canada, France and Sweden, principal return in the US dollar and in local currency against yield change.

Sources: JPMorgan Chase; BIS calculations.

This procyclical mechanism is also borne out in formal empirical analysis (Hofmann et al (2019); see also the right-hand panel of Graph 4). A depreciation of EME currencies against the US dollar is followed by a significant increase in local currency bond spreads, driven by higher credit risk premia. Quantitatively, a $1 \%$ depreciation shock leads to an increase in EME bond spreads of up to 9 basis points. This implies that the $10 \%$ depreciation of EME currencies that we have seen since early March could expand EME spreads by up to 90 basis points, which compares with an actual increase in EME spreads of roughly 150 basis points since mid-February (Graph 1, right-hand panel). 


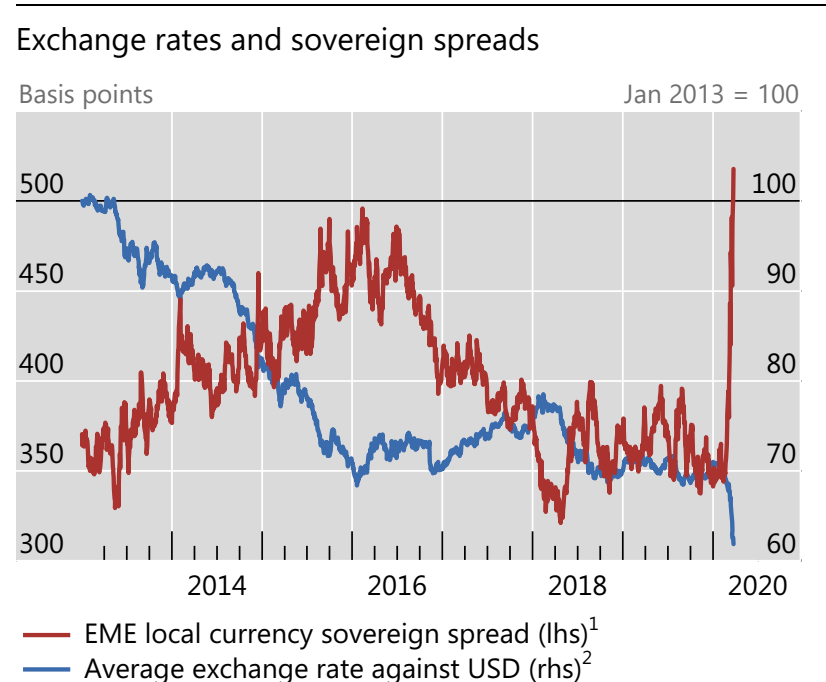

Impact of exchange rate depreciation ${ }^{3}$

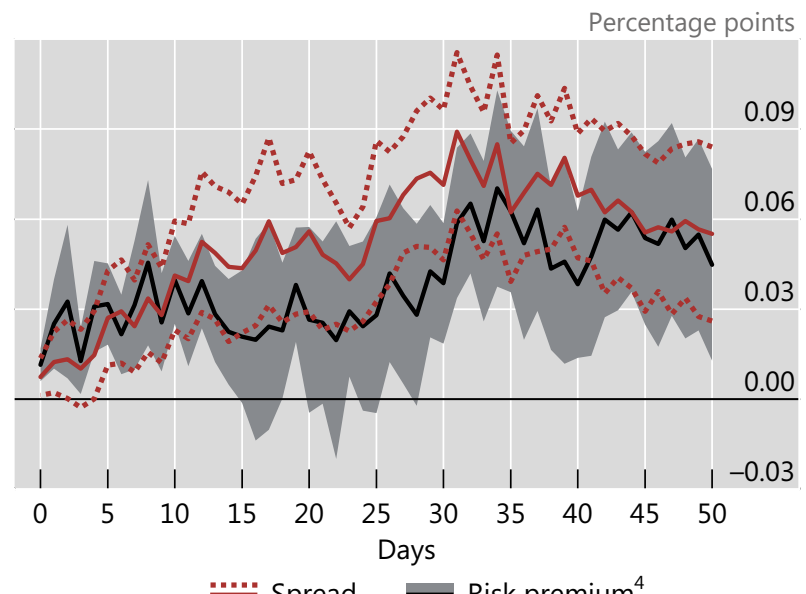

Risk premium ${ }^{4}$

1 JPMorgan GBI-EM Broad Diversified index spread over the 10-year US Treasury yield. ${ }^{2}$ Weighted average using the country weights (excluding DO, RO and UY) of the JPMorgan GBI-EM Broad Diversified index as of 28 February 2020. 3 Impact of a 1\% depreciation shock to the bilateral USD exchange rate (log exchange rate changes on days of US and euro area monetary policy news). ${ }^{4}$ Spread between the five-year local currency government bond yield and a synthetic local currency five-year yield given by the sum of the five-year US Treasury yield and the five-year cross-currency swap rate.

Sources: Hofmann et al (2019); Bloomberg; Datastream; JPMorgan Chase; BIS calculations.

\section{The role of sound policy frameworks}

The Covid-19 pandemic will be a stress test for EME central bank market operations and monetary policy frameworks. In order to meet the challenges posed by large swings in capital flows and exchange rates, many EMEs have adopted policy frameworks that combine inflation targeting with macroprudential tools and FX reserve accumulation (BIS (2019)). These frameworks have brought welcome stability to EMEs to date, and should help EMEs weather the Covid-19 fallout. Better anchored inflation expectations will mitigate the impact of exchange rate depreciation on inflation. Macroprudential policies also enhance the resilience of the financial system. Many EMEs have accumulated large FX reserves over the past decade (Graph 5, left-hand panel). These FX reserves can buffer the shocks from the Covid-19 crisis and alleviate financial stress on EMEs, as they enable central banks to lean against currency depreciation and capital outflows. In the wake of the taper tantrum, EMEs with larger reserves experienced smaller currency depreciations (right-hand panel). The same is likely to be true this time round.

Yet, in order to meet the challenge of large stock adjustments by global investors, EME central banks may need to expand their toolkit, taking up the role of a dealer or buyer of last resort. In particular, they may need deploy their balance sheets by providing targeted liquidity to market participants, by intermediating in the repo market or by purchasing domestic bonds. EME central banks are already adapting and moving fast in this direction. For instance, the central banks of Colombia, the Philippines, Poland and South Africa recently launched bond purchase programmes, while the Bank of Thailand introduced a mutual fund liquidity facility. ${ }^{1}$ More EME central banks may consider taking such measures if the EME bond market rout continues.

1 As early as 2008 and 2009, the Bank of Mexico swapped long-term securities for short-term securities via auctions in order to address stock adjustments by global investors in the wake of the Great Financial Crisis. 
Sound policy frameworks at the national level can be supported by credible and effective global and regional financial safety nets, reinforced by short-term liquidity support and bilateral lines from other central banks. The swap and repo facilities recently announced by the Federal Reserve have eased dollar funding conditions. Given the "dual" nature of the problem - with spreads and exchange rates spiralling in tandem - dollar lines will also quell domestic financial stringency. From a longer-term perspective, the development of a deep domestic institutional investor base will be key to further reducing EMEs' vulnerability to external financial shocks, such as the fallout from the Covid-19 pandemic that is now materialising (Carstens and Shin (2019), CGFS (2019), BIS (2019)).

\section{EME FX reserve buffers}

FX reserves

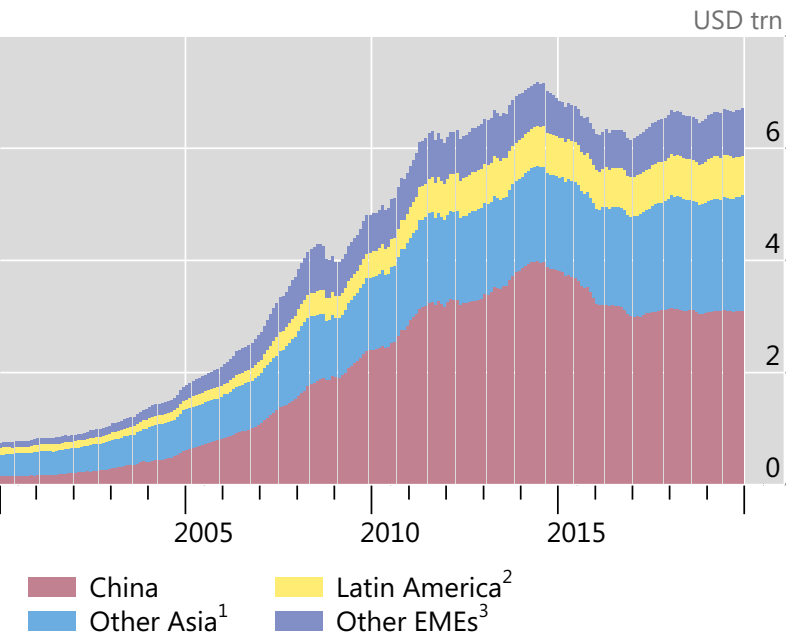

FX reserves cushion the impact of major shocks ${ }^{4}$

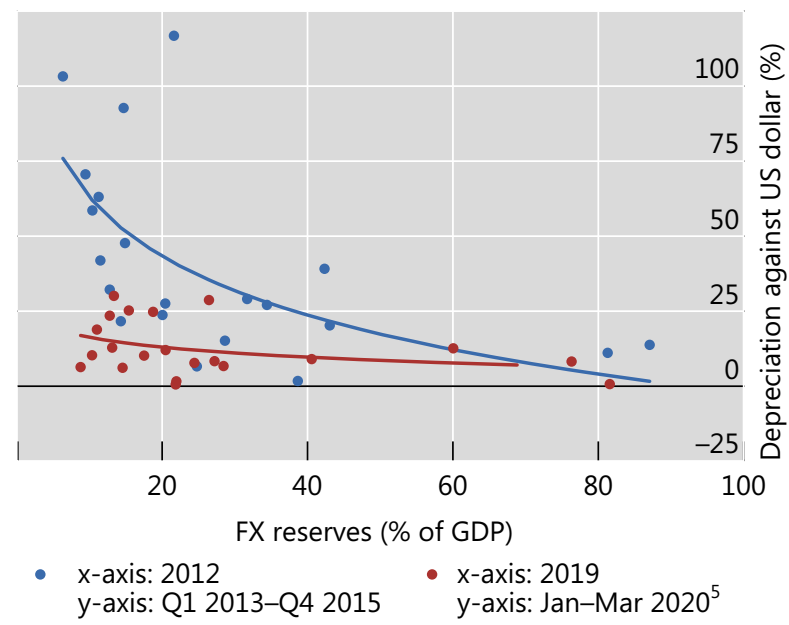

1 Hong Kong SAR, India, Indonesia, Korea, Malaysia, the Philippines, Singapore and Thailand. 2 Argentina, Brazil, Chile, Colombia, Mexico and Peru. ${ }^{3}$ The Czech Republic, Hungary, Poland, Russia, South Africa and Turkey. ${ }^{4}$ Based on 21 EMEs. 523 March 2020 versus 3 January 2020.

Source: IMF, International Financial Statistics and World Economic Outlook.

\section{References}

Arslanalp, S and T Tsuda (2014): "Tracking global demand for emerging market sovereign debt", IMF Working Papers, no WP/14/39.

Bank for International Settlements (BIS) (2019): "Monetary policy frameworks in EMES: inflation targeting, the exchange rate and financial stability", Chapter II, Annual Economic Report 2019, June.

Carstens, A and H S Shin (2019): "Emerging markets aren't out of the woods yet", Foreign Affairs, 15 March.

Committee on the Global Financial System (CGFS) (2019): "Establishing viable capital markets", CGFS Papers, no 62, January.

Eichengreen, B and R Hausmann (1999): "Exchange rates and financial fragility", in New Challenges for Monetary Policy, proceedings of the economic policy symposium sponsored by the Federal Reserve Bank of Kansas City in Jackson Hole, 26-28 August, pp 319-67.

Hofmann, B, I Shim and H S Shin (2019): "Bond risk premia and the exchange rate", BIS Working Papers, no 775 , March.

Hong Kong Monetary Authority (HKMA) (2019): "The double-edged sword of foreign participation in local currency government bond markets", Research Memorandum 14/2019. 


\section{Previous issues in this series}

No 4

6 April 2020

No 3

3 April 2020

No 2

2 April 2020

No 1

1 April 2020
The macroeconomic spillover effects of the pandemic on the global economy

Covid-19, cash, and the future of payments

Leverage and margin spirals in fixed income markets during the Covid-19 crisis

Dollar funding costs during the Covid-19

crisis through the lens of the FX swap market
Emanuel Kohlscheen, Benoît Mojon and Daniel Rees

Raphael Auer, Giulio Cornelli and Jon Frost

Andreas Schrimpf, Hyun Song Shin and Vladyslav Sushko

Stefan Avdjiev, Egemen Eren and Patrick McGuire

All issues are available on our website www.bis.org. 